\title{
Hepatoprotective activity of melittin on isoniazid- and rifampicin-induced liver injuries in male albino rats
}

\author{
Khalid Mohammed Naji ${ }^{12^{*}}$ (D, Bushra Yahya Al-Khatib ${ }^{3}$, Nora Saif Al-Haj ${ }^{3}$ and Myrene R. D'souza ${ }^{4}$
}

\begin{abstract}
Background: The present study investigated the ameliorative effect of melittin, a major polypeptide in the venom of honeybee (Apis mellifera), on isoniazid-(INH) and rifampicin-(RIF) induced hepatotoxicity in male albino rats.

Method: Thirty rats (140-200 g) were divided into five groups $(n=6)$ : normal control (NC) received normal saline orally ( $\mathrm{NaCl}, 0.9 \%$; toxic (T) group received INH + RIF (each rat received $100 \mathrm{mg} / \mathrm{kg}$, p.o.); melittin (Mel15, Mel30) groups (each rat received 15 or $30 \mu \mathrm{g} / \mathrm{kg}$ s.c); and normal recovery (NR) group received INH + RIF (each rat received $100 \mathrm{mg} / \mathrm{kg}$, p.o.). Blood and liver samples were collected for biochemical, hematological and histopathological studies respectively.

Results: The administration of melittin was found to prevent the antitubercular drug-induced alterations in the diagnostic markers; reduced glutathione (GSH), direct bilirubin (DB), total bilirubin (TB), aspartate aminotransferase (AST), alanine aminotransferase (ALT), lactate dehydrogenase (LDH), alkaline phosphatase (ALP), and total serum protein (TSP). Besides, hematological alterations were significantly high in Mel groups when compared to the toxic group. The NR group exhibited lower levels of DB, TB, ALP, LDH and TSP. In addition, treatment with melittin offered protection in the NR group with respect to MDA levels.

Conclusion: Evidence from this study suggests that melittin is beneficial for the prevention of acute hepatic failure in antitubercular drug-induced hepatoxicity and could be used as a potential therapeutic agent.
\end{abstract}

Keywords: Melittin, Bee venom, Hepatotoxicity, Tuberculosis, Rifampicin, Isoniazid

\section{Background}

Tuberculosis is a highly communicable disease affecting over one-third of the world's population and killing over 2 million people per year [1]. A meta-analytical study on the co-administration of isoniazid (INH) and rifampicin (RIF), the first-line drugs used for tuberculosis therapy indicated that they are associated with 2-6\% hepatotoxicity [2], acute liver injury and high mortality rate [3].

\footnotetext{
* Correspondence: khalid.m.naji@gmail.com

'Department of Chemistry, Faculty of Science, Sana'a University, Sana'a, Yemen

${ }^{2}$ Department of Chemical Ecology/Biological Chemistry, University of Konstanz, Universitätsstraße 10, 78464 Konstanz, Germany

Full list of author information is available at the end of the article
}

These drugs mediate the generation of highly reactive oxygen species (ROS), which act as a trigger of lipid peroxidation and a means for destruction of the plasma membrane [4]. RIF actively induces CYP2E1, a member of the cytochrome P450 family responsible for the breakdown of environmental chemicals and carcinogens. It also increases INH induced toxicity by stimulating the formation of the toxic metabolite hydrazine via amidase pathway. Hydrazine then reacts with the sulfhydryl group of glutathione (GSH), depleting its levels within the hepatocytes and causing cell death [2]. Combination chemotherapy with INH-RIH was found to stimulate the conversion of INH to isonicotinic acid, another

C C The Author(s). 2021 Open Access This article is licensed under a Creative Commons Attribution 4.0 International License, which permits use, sharing, adaptation, distribution and reproduction in any medium or format, as long as you give appropriate credit to the original author(s) and the source, provide a link to the Creative Commons licence, and indicate if changes were made. The images or other third party material in this article are included in the article's Creative Commons licence, unless indicated otherwise in a credit line to the material. If material is not included in the article's Creative Commons licence and your intended use is not permitted by statutory regulation or exceeds the permitted use, you will need to obtain permission directly from the copyright holder. To view a copy of this licence, visit http://creativecommons.org/licenses/by/4.0/ The Creative Commons Public Domain Dedication waiver (http://creativecommons.org/publicdomain/zero/1.0/) applies to the data made available in this article, unless otherwise stated in a credit line to the data. 
hepatotoxic product. The plasma half-life of acetyl hydrazine is further shortened by RIF as it is quickly converted to its active metabolites; thereby increasing the occurrence of liver necrosis [5].

Many traditional remedies employing herbal drugs continue to make a major contribution to health in terms of prevention and treatment of many diseases [6]. Venomous insects have long been used in scientific research and represent the basis of many traditional drugs [7]. Bee venom, a natural toxin produced by the honeybee (Apis mellifera) is known to relieve pain and treat inflammatory diseases, such as rheumatoid arthritis, in both humans and experimental animals [8, 9]. Bee venom comprises a variety of peptides, including melittin, adolpin, apamin, phospholipase A2 and mast cell degranulating peptide [10]. Melittin (MEL) is the principal toxin of bee venom accounting for approximately $50 \%$ of its dry matter. MEL is a small linear basic peptide with the chemical formula $\mathrm{C}_{131} \mathrm{H}_{228} \mathrm{~N}_{38} \mathrm{O}_{32}$, twenty-six amino acid long and weighs $2847.5 \mathrm{Da}$ [11]. It suppresses inflammation by inhibiting phospholipase (PLA) activity [12]. The protective effect of MEL on various inflammatory parameters has been reported by several investigators on acute liver inflammation [13], osteoarthritic chondrocytes [14], rheumatoid arthritis [15], and acute pancreatitis [16]. MEL was found to attenuate inflammation and fibrosis by inhibiting the NF- $\mathrm{kB}$ signalling pathway in liver fibrosis induced by thioacetamide. It decreases the rate of lethality, inhibits hepatocyte apoptosis and attenuates hepatic inflammatory responses. Recent reports in various disease models have proven the anti-inflammatory effects of MEL [17]. In the current study, we assessed the effects of melittin on antituberculosis drugs-induced hepatotoxicity via biochemical analysis, haematological and histological examination.

\section{Methods}

\section{Experimental animals}

The study was carried out according to the guidelines prepared by the National Academy of Sciences and published by the National Institute of Health [18].

Thirty adults, male, healthy rats Rattus rattus, weighing 140-200 g were collected from the animal house, Biology Department, Faculty of Science, Sana'a University, Sana'a. The animals were housed in the research laboratory, Department of Pharmaceutics, University of Science and Technology, Sana'a for two weeks. Two animals were kept in each standard metallic cage $(0.15 \times$ $0.20 \times 0.26 \mathrm{~m})$ and maintained under room temperature $\left(18-24{ }^{\circ} \mathrm{C}\right)$ with alternating $12 \mathrm{~h}$ light/dark cycle and $60 \%$ fresh air ventilation. The animals were provided with food pellets and water ad libitum. Collection trays were placed below the cages and daily cleaned. The amount of food and water taken by the rats were recorded every day, while the body weight was recorded every week.

\section{Experiment design and treatment}

After the adaptation period, the rats were randomly divided into five groups of six animals:

i. Normal control (NC) group: Rats received normal saline orally $(\mathrm{NaCl}, 0.9 \%)$ daily, throughout the experimental period.

ii. Toxic (T) group: Each rat received INH $(100 \mathrm{mg} / \mathrm{kg}$ body weight, p.o.), and RIF (100 mg/kg body weight, p.o.) for 21 days.

iii. Mel15 group: Each rat received INH $(100 \mathrm{mg} / \mathrm{kg}$ body weight, p.o.), and RIF (100 $\mathrm{mg} / \mathrm{kg}$ body weight, p.o.) for 21 days + MEL ( $15 \mu \mathrm{g} / \mathrm{kg}$ MEL, subcutaneously) for 15 days.

iv. Mel30 group: Each rat received INH $(100 \mathrm{mg} / \mathrm{kg}$ body weight, p.o.), and RIF (100 $\mathrm{mg} / \mathrm{kg}$ body weight, p.o.) for 21 days + MEL ( $30 \mu \mathrm{g} / \mathrm{kg}$ MEL, subcutaneously) for 15 days.

v. Normal recovery (NR) group: Each rat received INH (100 mg/kg body weight, p.o.), and RIF (100 $\mathrm{mg} / \mathrm{kg}$ body weight, p.o.) for 21 days. The animals were then allowed to recover for 15 days without any melittin.

All experiments were performed thrice within a period of 18 months during 2014-2016.

\section{Sample collection and preparation Blood samples}

After overnight fasting, all rats were anesthetized by slow subcutaneously administration of Ketamine/xylazine $(50 / 5 \mathrm{mg} / \mathrm{kg})$. At 08:00 AM, two sets of blood samples from the same animal were collected via the retroorbital venous plexus using microhematocrit capillary tubes. The first set of blood sample was added to an empty tube to obtain serum for biochemical analysis. The second set of blood sample was added to an EDTA containing tube to obtain plasma for the hematological studies.

\section{Tissue samples}

All rats were sacrificed under anesthesia by cutting the neck using a sharp blade and then dissected. The liver was harvested, weighed and washed immediately with ice-cold saline to remove as much blood as possible. Each liver sample was divided into two parts - one part was used for preparing crude extracts, while the second part was fixed in 10\% neutral-buffered formalin for histology analysis. 


\section{Preparing tissue extract}

Briefly $10 \%$ extracts were prepared by homogenizing the tissue in ice-cold $0.1 \mathrm{M}$ phosphate buffer ( $\mathrm{pH}$ 7.4) with Teflon homogenizer at $3000 \mathrm{rpm}$ for $10 \mathrm{~min}$. The homogenate was centrifuged at $15,000 \mathrm{rpm}$ for $30 \mathrm{~min}$ followed by lyophilization of the supernatant. The supernatant served as the source for reduced glutathione (GSH), lipid peroxidation (LPO) and total protein (TP) [19]. The preparation of tissues samples was carried out at the Tropical Disease Research Center-University of Science and Technology Hospital.

\section{Measurement of serum ALT, AST, ALP, TB and TSP}

Serum biochemical parameters such as direct bilirubin (DB), total bilirubin (TB), aspartate aminotransferase (AST), alanine aminotransferase (ALT), lactate dehydrogenase (LDH), alkaline phosphatase (ALP), and total serum protein (TSP) were determined using kits supplied by Roche Diagnostics and the Roche/Hitachi Analyzer [20] at Al-Aulaqi Specialized Medical Laboratory, Sana'a.

\section{Biochemical analysis of tissues}

The extent of lipid peroxidation was determined from the amount of thiobarbituric acid reactive substance (TBARS) formed by a reaction involving thiobarbituric acid [21]. The amount of reduced glutathione (GSH) [22] and total protein [23] were estimated in liver homogenate.

\section{Hematological assays}

The red blood cells (RBCs), total white blood cells ( $\mathrm{T}$ WBCs) count, differential leukocytes count, platelets, hemoglobin $(\mathrm{Hb})$, hematocrit (Hct), mean corpuscular hemoglobin $(\mathrm{MCH})$, mean corpuscular hemoglobin concentration $(\mathrm{MCHC})$, mean corpuscular volume $(\mathrm{MCV})$, and red cell distribution width (RDW-CV) were measured [24] using automated Hematology System, Sysmex XT-2000i at Al-Aulaqi Specialized Medical Laboratory, Sana'a.

\section{Histological analysis \\ Preparation of tissue samples}

The liver tissues were washed in ice normal saline solution, fixed in $10 \%$ formalin, dehydrated in graded alcohol (50-100\%) and embedded in paraffin. The tissue was cut $(3 \mu \mathrm{m})$ and stained with hematoxylin and eosin [25]. Sections were examined under a light microscope (Olympus microscope CX-21) and photographed by attached Olympus Camera DP21 (U-TV0.5XC-3).

\section{Histopathological quantitative analysis}

Quantitative analysis of the histopathological changes in the liver was averaged ( $n=6$ per group) using an ocular micrometer calibrated with a stage micrometer. The frequency of histopathological changes was based on an average obtained from an observation of 10-microscopic fields [26] with an area $625 \mu^{2}$ at $40 x$ or $400 x$. The histology work was performed in the Histology Lab, at the University of Science and Technology.

\section{Statistical analysis}

All data presented were expressed as mean \pm standard deviation of three repeated set of the experiments. Oneway analysis of variance (ANOVA) was used for analyzing statistical significances between the groups. This was followed by Tukey Multiple Comparisons using Prism 6 software (Graph Pad, San Diego, CA, USA). Values with $P<0.05$ was considered significant.

\section{Results}

\section{Body and liver weight}

Result of body weight showed visible changes during the course of experiment. We recorded the body weight of each group by comparing the mean difference of final and baseline body weight. The NC group of animals had a mean body weight difference around $42.83 \mathrm{~g}$. The $\mathrm{T}$ group showed a significant decrease $77.8 \%$ compared to the NC group, whereas, a significant increase of 75.18 and $88.25 \%$ was exhibited in Mel 15 and Mel 30 groups respectively compared to the $\mathrm{T}$ group $(P<0.05)$ (Table 1). At the end of the experiment, the mean of liver weight was $9.8 \mathrm{~g}$ for $\mathrm{NC}$ group. There were nonsignificant changes in the weight of the liver of the animals. The weight of liver increased by 36 and $48 \%$ in Mel 15 and Mel 30 groups respectively compared to the $\mathrm{T}$ group $(P<0.01)$ as shown in Table 1 .

\section{Biochemical markers}

A significant decrease in the levels of DB $(85 \%$ for Mel15 and Mel30), TB (80\% for Mel15 and 72\% for Mel30), LDH (48\% for Mel15 and 46\% for Mel30) $(P<$ 0.0001 ), ALT (47\% for Mel15 and 41\% for Mel30), ALP (43\% for Mel15 and $42 \%$ for Mel30) $(P<0.001)$, AST (52\% for Mel15 and 49\% for Mel30), TSP ( $0 \%$ for Mel15 and $7.3 \%$ for Mel30) $(\mathrm{P}<0.01)$ was seen compared to $\mathrm{T}$ group (Table 2). There was a significant decrease in $\mathrm{DB}$, TB, ALP $(P<0.0001)$, ALT, AST $(P<0.05)$ and LDH $(\mathrm{P}<0.001)$ levels in the Mel30 group when compared to the $\mathrm{T}$ group. On the other hand, there was a significant decrease in serum DB, TB $(\mathrm{P}<0.0001)$, ALP, TSP $(\mathrm{P}<$ $0.001)$ and LDH $(P<0.05)$ in the NR group when compared with the $\mathrm{T}$ group (Table 2).

\section{Antioxidant markers and total protein}

A significant increase in MDA was demonstrated in NR $(\mathrm{P}<0.0001)$ when compared with $\mathrm{T}$ group. On the other hand, there was an insignificant reduction in liver MDA 
Table 1 Body weight and liver weight of male rats receiving melittin post isoniazid and rifampicin-induced hepatotoxicity

\begin{tabular}{llllll}
\hline & NC & T & Mel15 & Mel30 & NR \\
\hline Baseline weight (g) & $151.8 \pm 6.2$ & $172.8 \pm 14.1$ & $176.8 \pm 17.7$ & $182.6 \pm 16.5$ & $172.87 \pm 32.2$ \\
Final weight (g) & $184.2 \pm 18.3$ & $174.7 \pm 24.3$ & $209 \pm 20.5$ & $220.5 \pm 18.1$ & $191.8 \pm 41.6$ \\
Difference (g) & $42.83 \pm 5.78$ & $9.5 \pm 3.32$ & $32.20 \pm 8.46^{b^{*}}$ & $37.8 \pm 5.9^{b^{*}}$ & $19.71 \pm 8.22$ \\
Liver weight (g) & $9.788 \pm 1.05$ & $7.57 \pm 1.26$ & $10.26 \pm 0.99$ & $11.28 \pm 2.38^{b^{* *}}$ & $9.08 \pm 2.23$ \\
\hline
\end{tabular}

Results are expressed as mean \pm SD $(n=6)$

$N C$ control, $T$ Toxic, Mel15: treated by $15 \mu \mathrm{g}$ Melittin, Mel30 treated by $30 \mu \mathrm{g}$ Melittin, $N R$ Normal recovery

${ }^{*} P<0.05 ;{ }^{* *} P<0.01$; b: significant Vs T group

in Mel15 and Mel30 groups (Fig. 1a). Furthermore, a significant increase in GSH level was observed in the Mel15 $(P<0.01)$ and Mel30 $(P<0.05)$ groups compared with the $\mathrm{T}$ group after 15 days of treatment. No significant difference in GSH level was observed in the NR group compared to the $\mathrm{T}$ group (Fig. 1b).

Also, a significant decrease in the total protein content was noted in Mel30 group $(P<0.05)$ when compared with $\mathrm{T}$ group. No significant changes between the rats that received Mel15 and $\mathrm{T}$ group was seen (Fig. 1c).

\section{Haematological parameters}

After administration of MEL for 15 days, a significant decline in BAS and MCHC $(P<0.0001)$ when compared to $\mathrm{T}$ group was reported. A significant increase was found in Mel30 group for WBCs $(\mathrm{P}<0.0001)$, NEU, Hb, PLT and RDW- CV $(P<0.01)$, Hct and MCV $(P<0.001)$, EOS and MCH $(P<0.05)$, while BAS and MCHC were significant decreased $(\mathrm{P}<0.05)$ in comparison with $\mathrm{T}$ group. On the other hand, there was a significant increase in WBCs and $\mathrm{Hb}$ $(\mathrm{P}<0.05)$, NEU $(P<0.001)$, EOS, Hct, $\mathrm{MCH}(P<0.01)$ and MCV $(\mathrm{P}<0.0001)$. There a significant decrease in BAS, MCHC $(P<0.0001)$ in the NR group compared to the $\mathrm{T}$ group (Table 3 ). Moreover, LYM and MON in groups NC, T, Mel15, Mel30 and NR had no statistical changes.

\section{Histopathology}

A qualitative assay for histological lesions showed exhibited a central vein and normal hepatocytes (Fig. 2a). Liver sections of hepatotoxic group revealed severe histopathological lesions as shown in Table 4 and Fig. 2 (b, c, d \& e). Mel15 group demonstrated significantly lower scores of hemorrhage and congestion $(P<0.001)$, ballooned hepatocytes and inflammation $(P<0.01)$, while the greatest decrease was detected for necrosis, fibrosis and amyloids $(P<0.0001)$ when compared to T group as shown in Table 4 and Fig. 2f.

Furthermore, Mel30 group had significantly decreased scores for congestion and fibrosis $(\mathrm{P}<0.001)$, and inflammation $(\mathrm{P}<0.01)$. The greatest decrease was however detected with necrosis and amyloids $(\mathrm{P}<0.0001)$ as compared to $\mathrm{T}$ group (Table 4 and Fig. $2 \mathrm{~g}$ ). In addition, the NR group had significantly decreased scores of hemorrhages $(\mathrm{P}<0.001)$, and steatosis $(P<0.05)$, while showing significant reduction in necrosis $(\mathrm{P}<0.05)$, and amyloids $(\mathrm{P}<0.0001)$, when compared with $\mathrm{T}$ group (Table 4 and Fig. 2h).

\section{Discussion}

The present investigation examines the protective effects of the peptide, melittin a major component of bee venom against hepatotoxicity induced by the coadministration of Isoniazid (INH) + Rifampicin (RIF) in adult male albino rats for 21 days. A dose-weight

Table 2 Biochemical parameters of male rats receiving melittin post isoniazid and rifampicin-induced hepatotoxicity

\begin{tabular}{llllll}
\hline & NC & T & Mel15 & Mel30 & NR \\
\hline DB $(\mu \mathrm{mol} / \mathrm{l})$ & $1.0 \pm 0.451$ & $7.05 \pm 1.84^{\mathrm{a}^{* * * *}}$ & $1.0 \pm 0.38^{\mathrm{b}^{* * * *}}$ & $1.0 \pm 0.27^{\mathrm{b}^{* * * *}}$ & $1.0 \pm 0.31^{\mathrm{b}^{* * * *}}$ \\
TB $(\mu \mathrm{mol} / \mathrm{l})$ & $1.6 \pm 0.94$ & $10.45 \pm 2.13^{\mathrm{a}^{* * * *}}$ & $2 \pm 1.05^{\mathrm{b}^{* * * *}}$ & $2.82 \pm 1.499^{\mathrm{b}^{* * * *}}$ & $2.87 \pm 0.899^{\mathrm{b}^{* * * *}}$ \\
ALT $(\mathrm{U} / \mathrm{L})$ & $26.83 \pm 11.44$ & $73.5 \pm 16.99^{\mathrm{a}^{* * *}}$ & $38.5 \pm 14.27^{\mathrm{b}^{* *}}$ & $44.33 \pm 15.93^{\mathrm{b}^{*}}$ & $50.33 \pm 17.44$ \\
AST $(\mathrm{U} / \mathrm{L})$ & $92.17 \pm 31.64$ & $288.3 \pm 147.7^{\mathrm{a}^{* *}}$ & $137.7 \pm 15.81^{\mathrm{b}^{*}}$ & $147 \pm 32.83^{\mathrm{b}^{*}}$ & $183.2 \pm 79.05$ \\
ALP (U/L) & $187.2 \pm 25.86$ & $286.5 \pm 53.07^{\mathrm{a}^{* * *}}$ & $164.2 \pm 19.59^{\mathrm{b}^{* * * *}}$ & $166.5 \pm 18.41^{\mathrm{b}^{* * * *}}$ & $189 \pm 27.41^{\mathrm{b}^{* * *}}$ \\
LDH $(\mathrm{U} / \mathrm{L})$ & $762 \pm 63.68$ & $3046 \pm 768.1^{\text {*****}}$ & $1577 \pm 338.4^{\mathrm{b}^{* * * *}}$ & $1640 \pm 693.3^{\mathrm{b}^{* * *}}$ & $2155 \pm 261.2^{\mathrm{b}^{*}}$ \\
TSP $(\mathrm{g} / \mathrm{L})$ & $66 \pm 8.37$ & $75.5 \pm 0.84^{\mathrm{a}^{* *}}$ & $76 \pm 1.67$ & $70 \pm 2.76$ & $63.5 \pm 2.51^{\mathrm{b}^{* * *}}$ \\
\hline
\end{tabular}

Results are expressed as mean \pm SD $(n=6)$

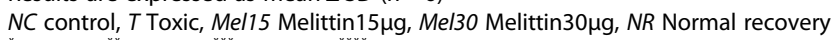

${ }^{*} \mathrm{P}<0.05 ;{ }^{* *} \mathrm{P}<0.01 ;{ }^{* * *} \mathrm{P}<0.001 ;{ }^{* * * *} \mathrm{P}<0.0001$

a: significant Vs NC group, b: significant Vs T group 


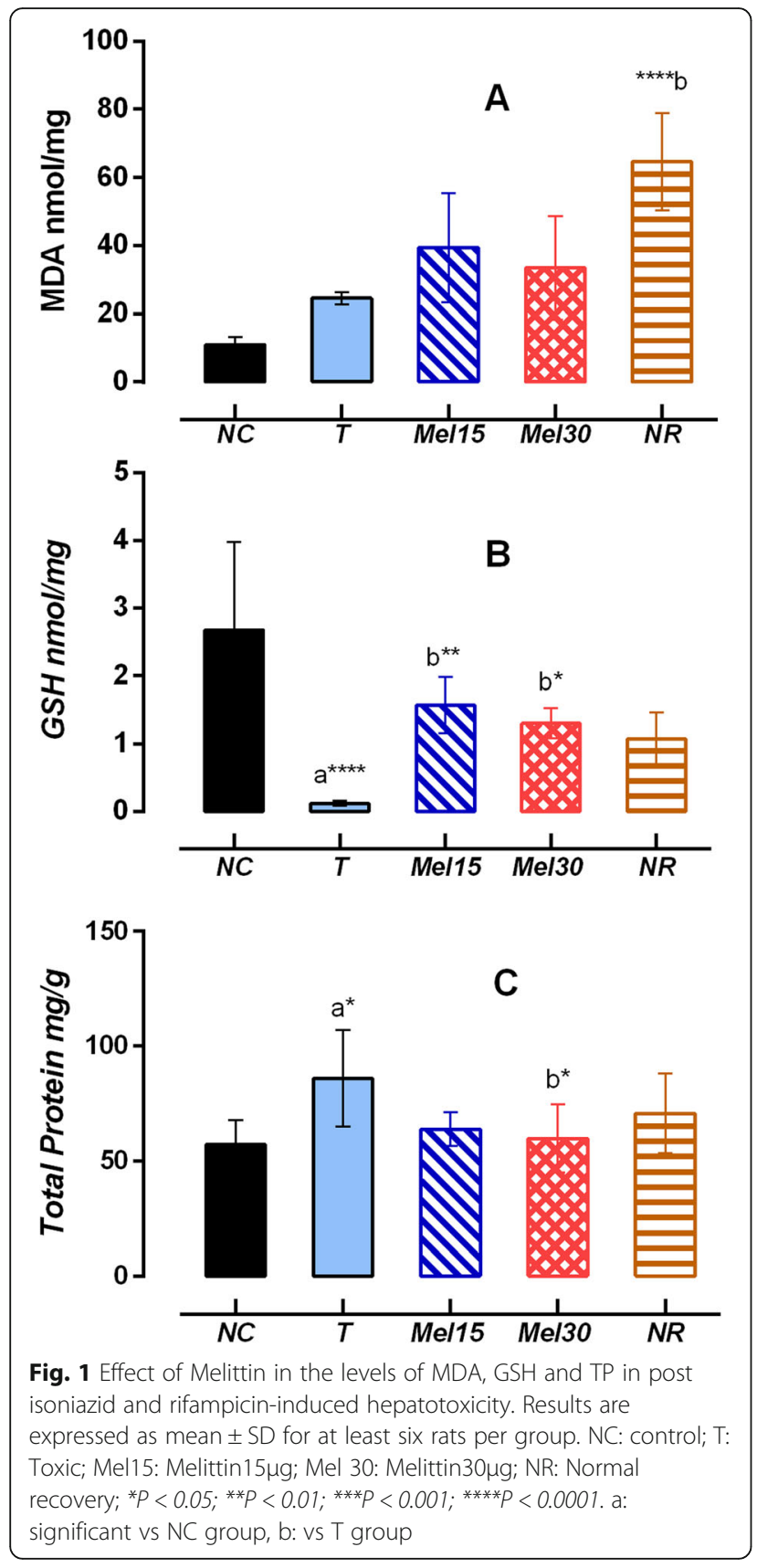

dependent increase indicated that Mel30 was more effective than Mel15in treatment. Thus, it could imply that treatment with MEL improves the food intake, food palatability, metabolic processes, and consequently increased the body weight and liver/body weight ratio of rats that received INH + RIF rats.

Increase in activity of the enzymes ALT and AST is indicative of massive hepatocellular disease and is linked to acute hepatic necrosis [27]. Chronic liver disease is diagnosed by a large increase of mitochondrial AST in the serum following extensive tissue necrosis [28]. The increase in ALP activity in the T group (Table 2) is related to improper bile flow through the gallbladder and bile duct into the intestine [29], leaky tight junctions between the canaliculi wall cells [30], overproduction and release of ALP into the blood due to hepatobiliary injury and cholestasis [31]. The decline reported in Mel15 and Mel30 samples indicates a positive effect of MEL on ALP in the treatment used which reflect the role of melittin on reduction of cholestasis and hepatobiliary cell injury through reduction in ductular reactions and cholangiocyte proliferation [32]. The high serum levels of LDH reported in the T group is an important index of liver cell damage probably due to hepatocellular necrosis [33]. Mel15 and Mel30 treatment demonstrated a considerable decline in serum LDH activity indicating its contribution towards the protection of liver epithelial cells from damage through the inhibition of inflammatory cytokines and apoptosis as reported previously [34]. It could also be suggested that the administration of MEL may prevent liver damage related to the maintenance of plasma membrane integrity, thereby suppressing the leakage of enzymes through membranes. Additionally, MEL may also exhibit hepatocurative activity against the hepatotoxicity induced by a combination of INH and RIF drugs [35]. Mel15 and Mel30 treatment reduced the elevation of AST and ALT activities; with MEL groups showing greater improvement than the NR group. From the results obtained, Mel15 treatment provided a better reduction in serum levels of the AST and ALT when compared to Mel30 treatment. This indicates that Mel at $15 \mu \mathrm{g} / \mathrm{kg}$ is more efficacious than $30 \mu \mathrm{g} / \mathrm{kg}$ for reducing the biochemical parameters induced by INH + RIF. This may correspond to the adverse effect of high amount of melittin that accumulates and leads to cell lysis [32]. Although Melittin treatment significantly reduced the liver enzymes levels, they remain relevantly high compared to control (NC), which may have resulted from the massive damage of liver generated by INH + RIF.

Anti-tubercular drugs through oxidative stress causes cellular damage as well as dysfunction of the hepatic antioxidant defense system [36]. Enhanced susceptibility of the hepatocyte cell membrane to anti-tubercular drugs induces peroxidative damage which increases the activity of diagnostic marker enzymes (Table 2) in the systemic circulation. Mel15 and Mel30 treatment exhibited a statistically significant $(P<0.0001)$ decline in MDA levels in NR group when compared to $\mathrm{T}$ group (Fig. 1) indicating its ability to prevent hepatocellular damage [37]. The increase in GSH (Fig. 1) upon Mel15 and Mel30 treatment compared to $\mathrm{T}$ group suggests its capability of preventing the depletion of antioxidant defenses by shifting the prooxidant-antioxidant balance to negate oxidative stress-induced cell death [38]. These findings were in similarity with results in GalN/ LPS- induced liver injury [39]. 
Table 3 Complete blood count in male rats that received melittin post isoniazid and rifampicin-induced hepatotoxicity

\begin{tabular}{|c|c|c|c|c|c|}
\hline & $\mathrm{NC}$ & $T$ & Mel 15 & Mel 30 & NR \\
\hline$\overline{W B C s}\left(\times 10^{3} / \mu \mathrm{l}\right)$ & $8.75 \pm 1.19$ & $5.45 \pm 2.09$ & $11.91 \pm 1.32^{b^{* * * *}}$ & $14.13 \pm 2.78^{b^{* * * *}}$ & $9.525 \pm 2.00^{b^{*}}$ \\
\hline LYM (\%) & $70.12 \pm 7.82$ & $79.23 \pm 7.44$ & $75.77 \pm 4.19$ & $70.52 \pm 9.36$ & $67.67 \pm 11.65$ \\
\hline MON (\%) & $4.55 \pm 2.20$ & $4.433 \pm 2.12$ & $7.117 \pm 2.38$ & $5.1 \pm 2.18$ & $5.75 \pm 1.86$ \\
\hline NEU (\%) & $19.5 \pm 4.33$ & $5.633 \pm 1.09^{a^{* *}}$ & $13.73 \pm 2.24$ & $21.17 \pm 8.98^{b * *}$ & $22.85 \pm 9.88^{b * * *}$ \\
\hline EOS (\%) & $1.15 \pm 0.23$ & $1.22 \pm 0.26$ & $3.23 \pm 1.55^{\mathrm{b}^{*}}$ & $3.48 \pm 1.43^{b^{*}}$ & $3.65 \pm 1.36^{b^{* *}}$ \\
\hline BAS (\%) & $0.08 \pm 0.04$ & $9.483 \pm 4.41^{a^{* * * * *}}$ & $0.15 \pm 0.05^{\mathrm{b} * * * *}$ & $0.1 \pm 0.0^{b^{* * * *}}$ & $0.08 \pm 0.04^{b * * * *}$ \\
\hline $\left.\mathrm{RBC}(\mathrm{s}) \times 10^{6} / \mu \mathrm{l}\right)$ & $9.033 \pm 0.852$ & $7.755 \pm 0.26^{a^{* *}}$ & $7.90 \pm 0.22$ & $7.952 \pm 0.69$ & $7.305 \pm 0.34$ \\
\hline $\mathrm{Hb}(\mathrm{g} / \mathrm{dl})$ & $15.18 \pm 0.80$ & $13.03 \pm 0.89^{\mathrm{a}^{* *}}$ & $14.88 \pm 0.32^{b^{* *}}$ & $15.17 \pm 0.74^{b^{* *}}$ & $14.5 \pm 1.17^{b^{*}}$ \\
\hline Hct (\%) & $48.78 \pm 2.67$ & $40.67 \pm 2.28^{\mathrm{a}^{* * *}}$ & $48.22 \pm 1.90^{\mathrm{b} * *}$ & $49.17 \pm 2.47^{b^{* * *}}$ & $47.6 \pm 4.46^{b^{* *}}$ \\
\hline$M C V(f L)$ & $65.3 \pm 3.31$ & $52.4 \pm 1.69^{9^{* * * * *}}$ & $61.03 \pm 2.11^{\mathrm{b**}}$ & $62.12 \pm 3.81^{b^{* * *}}$ & $65.23 \pm 5.48^{b * * * *}$ \\
\hline MCH (pg) & $20.32 \pm 0.79$ & $17.52 \pm 0.65^{\mathrm{a}^{* * *}}$ & $18.85 \pm 0.35$ & $19.12 \pm 1.15^{b^{*}}$ & $19.85 \pm 1.27^{b^{* *}}$ \\
\hline $\mathrm{MCHC}(\mathrm{g} / \mathrm{dL})$ & $31.13 \pm 0.41$ & $33.37 \pm 0.38^{\mathrm{a}^{* * * * *}}$ & $30.90 \pm 0.99^{b^{* * * *}}$ & $30.83 \pm 0.36^{b^{* * * *}}$ & $30.5 \pm 0.97^{b^{* * * *}}$ \\
\hline $\operatorname{PLT}\left(\times 10^{3} / \mu \mathrm{l}\right)$ & $777 \pm 68.9$ & $427.5 \pm 146.5^{\mathrm{a}^{* *}}$ & $827.8 \pm 76.3^{b^{* * *}}$ & $794.5 \pm 130.6^{b^{* *}}$ & $607.7 \pm 246.4$ \\
\hline RDW-CV (\%) & $18.22 \pm 2.1$ & $24.35 \pm 2.1^{a^{* * * *}}$ & $27.1 \pm 1.84$ & $28.65 \pm 1.93^{b^{* *}}$ & $24.75 \pm 1.56$ \\
\hline
\end{tabular}

Results are expressed as mean \pm SD $(n=6)$

WBCs White Blood Cells; Lym lymphocytes; Mon: Monocytes; Neu Neutrophils; EOS Eosinophils; Bas Basophils; RBCs Red Blood Cells; Hb Hemoglobin; Hct

Hematocrit; MCV Mean corpuscular volume; MCH Mean Corpuscular Hemoglobin; MCHC Mean corpuscular Hemoglobin concentration; PLT platelets; RDW-CV Red blood cell distribution width - Coefficient of Variation

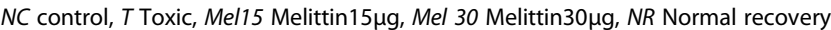

${ }^{*} \mathrm{P}<0.05 ;{ }^{* *} \mathrm{P}<0.01 ;{ }^{* * *} \mathrm{P}<0.001 ;{ }^{* * * *} \mathrm{P}<0.0001$. a: significant $\mathrm{Vs} \mathrm{NC}$ group, b: significant Vs T group

Anti-tubercular drugs have been recorded to cause hemolytic and aplastic anemia by the depression of the bone marrow [40, 41], with INH and its metabolite in particular affecting the erythroid precursor cells [42, 43]. Furthermore, INH binds to pyridoxine (vitamin B6), depleting its levels and causing anemia [44]. The increase in hematological parameters such as WBC, MON, NEU, EOS, Hct, PLT and RDW-CV in Mel15 and Mel30 groups when compared to the $\mathrm{T}$ group and NR group is suggestive of the role of MEL in ameliorating the hepatotoxicity induced by INH and RF [45]. Decrease in $\mathrm{Hb}$ levels is probably due to INH-mediated inhibition of heme synthesis by depressing $\delta$-aminolevulinic acid (ALA) synthetase, the first and rate-limiting enzyme in the heme synthesis pathway [46]. The result of this study revealed that MEL treatment could reverse the decline in Hb levels seen in $\mathrm{T}$ and NR groups (Table 3). The decrease in $\mathrm{MCV}$ and $\mathrm{MCH}$, indicative of microcytic hypochromic anemia is reported in all groups. Mel15 and Mel30 treatment could reverse this condition even though NR exhibited a higher recovery. However, Mel15 and Mel30 treatment did reduce MCHC when compared to $\mathrm{T}$ and NR group (Table 3). The significant decrease in platelets reported in T and NR groups (Table 3) is related to increased thrombocytopenia [46] possibly by RIF binding non-covalently to thrombocyte membrane glycol-proteins IIb/IIIa or Ib/IX to produce compound epitopes or induce conformational changes [47]. Treatment with Mel15 and Mel30 was shown to increase PLT (Table 3) providing better chances of reversing thrombocytopenia-induced by INH and RH. Basophil count significantly raising is very rare, but if seen, indicates myeloproliferative disorder or other more obscure causes [48]. Treatment with Mel15 and Mel30 reversed the increase in BAS, reducing it to almost NC levels (Table 3) which refers the high power of melittin as an antiinflammation agent. The increase in WBCs, NEU, EOS, $\mathrm{Hb}, \mathrm{Hct}, \mathrm{MCV}, \mathrm{MCH}$ and PLT suggests a positive effect of MEL against blood coagulation, triggering of erythrocytes formation and the regeneration of leucocytes and erythrocytes [49]. The increase of EOS in Mel15 and Mel30 groups may be due to the allergenic nature of melittin. This result was affirmed when several patients taking MEL complained from allergy symptoms [50].

A considerable decline was reported with Mel15 and Mel30 treatments This explains the decrease in TP levels in the tissues of rats that received MEL (Fig. 1c). Vasodilation observed to be the highest in $\mathrm{T}$ group (Table 4), induced by the action of histamine on vascular smooth muscle leads to increased permeability of the microvasculature, causing the outpouring of protein-rich fluid into extravascular tissues [19]. The vessels diameter decreased upon Mel15 and Mel30 treatment resulting in decreased concentration of red blood cells in small vessels, decreased viscosity of blood and reduced chances of engorgement of the small vessels. Thereby, the condition of stasis observed in the $\mathrm{T}$ group is reduced in MEL groups. Ballooned cells seen in large number in the $\mathrm{T}$ group are formed by excess water accumulation in the 

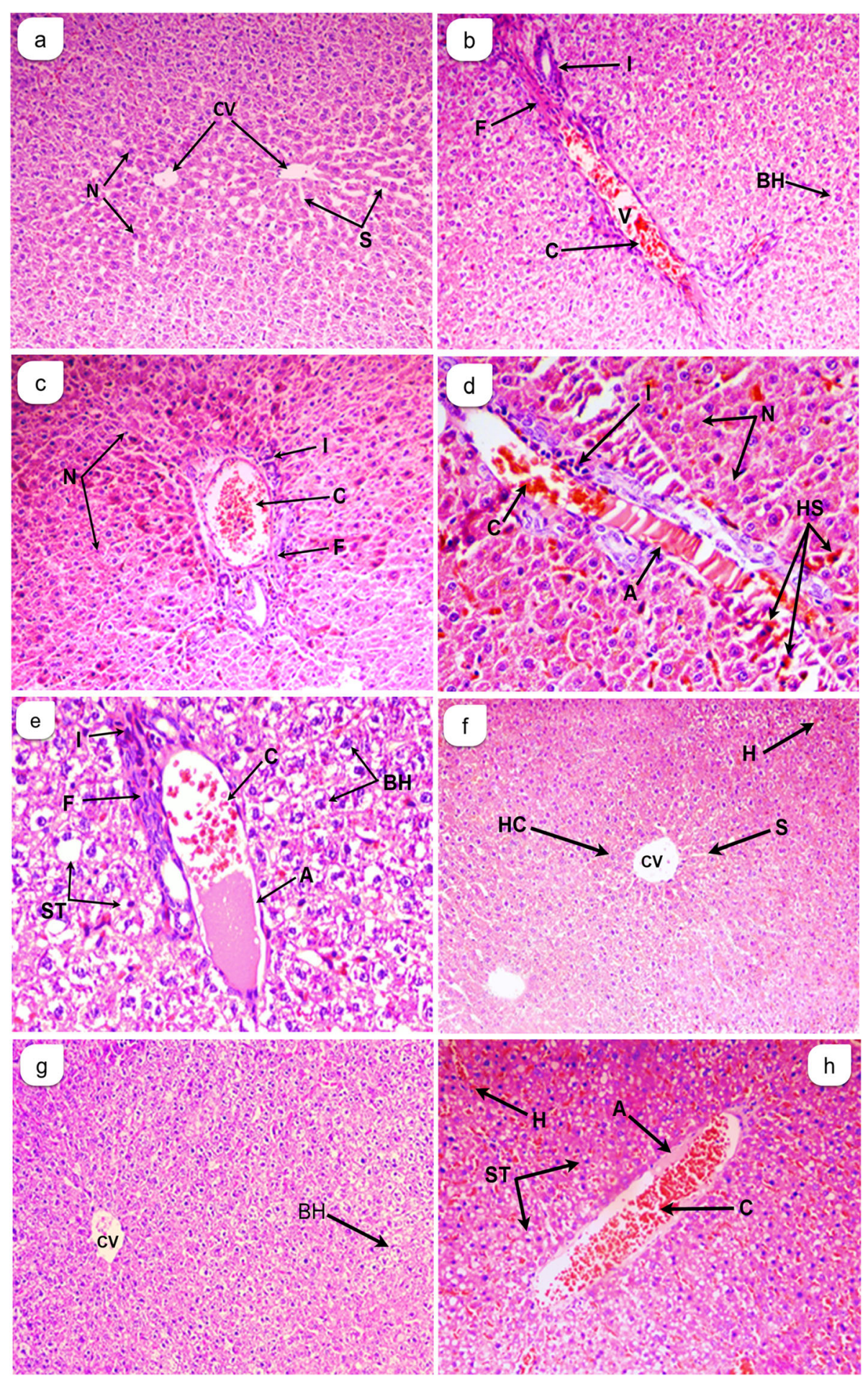

Fig. 2 Cross sections in liver of rats showed the effect of Melittin on liver tissues in post isoniazid and rifampicin-induced hepatotoxicity. (a): Normal control (NC); (b): toxic group (T); (c): treated group $15 \mu \mathrm{g}$ Melittin; (d): treated group $30 \mu \mathrm{g}$ Melittin (Mel 30); (e): Normal recovery group (NR). (a): Normal group (N), 200x; (b \& c): Toxic group (T), 200x; (d \& e): Toxic group(T) 400x; (f): Mel 15 mg, 200x; (g): Mel 30 mg, 200x; (h): Normal recovery group (NR) 200x. Histological abbreviations: Amyloids (A), Congested blood vessel (C), Ballooned hepatocytes (BH), Inflammation (I), Necrosis $(N)$, Vasodilation (V), Fibrosis (F), Hemorrhage $(H)$, Steatosis (ST), Hepatocytes (HC), Central vein (CV), Sinusoid (S) and Hemosiderin-laden macrophages (HS) 
Table 4 In situ evaluation of liver from rats that received melittin post isoniazid and rifampicin-induced hepatotoxicity

\begin{tabular}{|c|c|c|c|c|c|}
\hline & NC & $T$ & Mel15 & Mel30 & NR \\
\hline \multirow[t]{2}{*}{ Amyloids } & - & ++++ & - & - & + \\
\hline & $1.33 \pm 0.52$ & $17.5 \pm 6.47^{\mathrm{a}^{* * * * *}}$ & $2.67 \pm 1.21^{b^{* * * *}}$ & $1.5 \pm 0.55^{b^{* * * *}}$ & $3.83 \pm 1.72^{b^{* * * *}}$ \\
\hline \multirow[t]{2}{*}{ Congestion } & + & ++++ & + & + & +++ \\
\hline & $1.33 \pm 0.52$ & $6.67 \pm 1.36^{\mathrm{a}^{* * * *}}$ & $2.4 \pm 1^{\mathrm{b}^{* * *}}$ & $2.17 \pm 0.98^{\mathrm{b}^{* * * *}}$ & $5.17 \pm 2.56$ \\
\hline \multirow[t]{2}{*}{ Ballooned hepatocytes } & - & ++++ & + & ++ & ++ \\
\hline & $4 \pm 2$ & $86 \pm 39.43^{\mathrm{a}^{* * * * *}}$ & $30 \pm 11.65^{b^{* *}}$ & $49.4 \pm 17.81$ & $54.3 \pm 19.79^{\mathrm{a}^{* *}}$ \\
\hline \multirow[t]{2}{*}{ Inflammation } & - & ++++ & ++ & ++ & ++++ \\
\hline & $0.83 \pm 0.41$ & $4.5 \pm 0.84^{\mathrm{a}^{* * * * *}}$ & $2.5 \pm 1.0^{b^{* *}}$ & $2.5 \pm 1.2^{b^{* *}}$ & $4.4 \pm 1.0$ \\
\hline \multirow[t]{2}{*}{ Necrosis } & + & ++++ & + & + & +++ \\
\hline & $13.17 \pm 4.8$ & $64.83 \pm 17.2^{\mathrm{a}^{* * * * *}}$ & $23.17 \pm 10.1^{b^{* * * *}}$ & $22.33 \pm 4.1^{\mathrm{b****}}$ & $43.5 \pm 14.3^{\mathrm{b}^{*}}$ \\
\hline \multirow[t]{2}{*}{ Vasodilation } & - & ++++ & ++ & +++ & ++++ \\
\hline & $1.8 \pm 0.41$ & $16.3 \pm 4^{a^{* * *}}$ & $11.2 \pm 4.7$ & $12.5 \pm 4.76$ & $20.3 \pm 7.2$ \\
\hline \multirow[t]{2}{*}{ Fibrosis } & - & +++ & - & + & ++++ \\
\hline & $0.83 \pm 0.41$ & $6.83 \pm 2.0^{\mathrm{a}^{* * * *}}$ & $1.3 \pm 0.5^{b^{* * * *}}$ & $1.8 \pm 0.4^{b^{* * *}}$ & $7.3 \pm 3.2$ \\
\hline \multirow[t]{2}{*}{ Hemorrhage } & - & +++ & + & ++ & ++++ \\
\hline & $1.5 \pm 0.55$ & $5.5 \pm 0.55^{\mathrm{a}^{* * * *}}$ & $2.13 \pm 0.95^{5^{* * *}}$ & $4.5 \pm 2.1$ & $9.167 \pm 1.17^{b^{* * *}}$ \\
\hline \multirow[t]{2}{*}{ Steatosis } & - & + & - & - & ++++ \\
\hline & $1.3 \pm 0.5$ & $16.5 \pm 5.1$ & $3 \pm 1.1$ & $6.67 \pm 1.6$ & $48.5 \pm 19.9^{b^{* * * *}}$ \\
\hline
\end{tabular}

Results are expressed as mean \pm SD $(n=6)$

The histopathological changes were based on the average obtained from an observation of 10-microscopic fields with an area $625 \mu m^{2}$ at $40 x$ or $400 x$

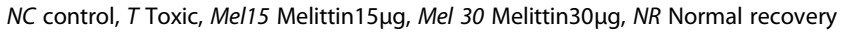

Damages graded as follows: -, absent; + , trace $(1-25 \%) ;++$, mild $(25-50 \%) ;+++$, moderate $(50-75 \%) ;++++$, severe $(75-100 \%) .{ }^{*} \mathrm{P}<0.05 ;{ }^{* *} \mathrm{P}<0.01$;

${ }^{* * *} \mathrm{P}<0.001 ;{ }^{* * * *} \mathrm{P}<0.0001$

a: significant Vs NC group, b: significant Vs T group

vacuoles as a result of the failure of active membrane transport due to loss of ATP as the energy source [51]. Number of ballooned cells in the liver of the Mel15 and Mel30 groups reduced when compared to $\mathrm{T}$ and NR groups (Table 4), suggesting that melittin possesses ameliorating effect of the active membrane transport.

In our study, necrosis observed as one of the most distinct pathological features of INH + RIF in liver sections. It was seen to decline upon Mel15 and Mel30 treatments when compared to $\mathrm{T}$ and NR groups, thereby reflecting the protective role of melittin from the necrosis produced by INH-RIF (Table 4). Fibrosis was reported to be highest in NR and T groups (Table 4, Fig. 2) possibly due to the activation of hepatic stellate cell (HSC) and their phenotypic transformation into myofibroblasts, possessing pro-fibrogenic role $[52,53]$. The condition of fibrosis was found to decline considerably in groups that received Mel15 and Mel30 (Table 4) which indicates the role of melittin in preventing INHRIF- induced liver fibrosis by inhibiting liver inflammation. The behavior was also reported in previous experiments that showed significant inhibitory action in melittin groups when compared to the toxic groups [54, 55]. Melittin was found to suppress proinflammatory cytokine expression via nuclear factor (NF)- $\mathrm{kB}$ signaling pathway in hepatic stellate cells cultured with TNF- $\alpha$ [54]. Furthermore, the fibrotic gene expression in response to thioacetamide- induced liver fibrosis was found to decrease in the presence of melittin [54]. The anti-apoptotic nature of melittin was illustrated in TNFa/actinomycin D-induced apoptosis in hepatocytes where it prevented TNF- $\alpha /$ Act D-induced activation of bcl-2 family of proteins, caspase and poly ADP-ribose polymerase (PARP)-1 [55]. In addition, it was reported that the NF- $\mathrm{kB}$ decreased on account of degradation of phosphorylation of ІкB kinase (p-IKK) as well as NF- $\kappa B$ DNA binding activity in TNF- $\alpha /$ Act D-treated hepatocytes. The suppression in apoptosis could be explained by treatment with melittin [55].

Melittin also protects against LPS-induced acute kidney injury by attenuating the production of renal and systemic levels of cytokines, preventing immune cell accumulation and by suppression of NF-kB pathway. It decreases the expression of NADP oxidase-4 while enhancing nuclear factor erythroid-2 related factor (Nrf2) mediated antioxidant defenses. This change inhibits apoptotic and necrotic renal cell death following treatment with LPS [56].

The decrease in amyloid deposition in hepatocytes in rats that received Mel can be explained by the work 
done on LPS-induced inflammation in BV2 microglial cells [57]. In this study, hepatocytes co-treated with LPS and melittin exhibited decreased expression of IL-6, IL$1 \beta$, and TNF- $\alpha$ and a corresponding improvement in motor function compared to the control [58]. This behavior was explained by improved proteasomal function along with decline in TNF- $\alpha$ and the corresponding decrease in Map 2, a marker for neuronal cell function [58].

Our results further strengthened the role of melittin in reducing the high rate of lethality, chronic liver injury, attenuating hepatic inflammatory responses and inhibiting hepatocyte apoptosis. Thus, it is clear from our findings that melittin might possess an ameliorative role in biological, biochemical, hematological and histological alterations against hepatotoxicity, induced by INH and RF. Also, Melittin can prevent necrosis and fibrosis in many diseases. These results present building blocks for performing further studies that will help in the treatment of some degenerative disease such as Alzheimer disease.

\section{Conclusions}

Novel drugs often developed from natural products such as toxins from bees, snakes and scorpions provide therapeutics for the treatment of inflammatory and neurodegenerative diseases. It is evident from this study that melittin protects isoniazid and rifampicin induced hepatotoxicity. Its use as an anti-inflammatory agent will depend on the development of innovative research protocols to validate its efficacy and safety. Modification of the toxic peptide could overcome the associated illeffects and pave a way for promoting novel pharmaceutical agents. We propose that melittin could be used as a potential therapeutic agent for attenuating acute liver injury and hepatic failure provided prerequisites are met to evade adverse effects.

\section{Abbreviations}

INH: Isoniazid; RIF: Rifampicin; MEL: Melittin; DTNB: 1,2 dithio-bis nitrobenzoic acid; TBA: Thiobarbituric acid; ALT: Alanine aminotransferase; AST: Aspartate aminotransferase; ALP: Alkaline phosphatase; LDH: lactate dehydrogenase; TSP: Total serum protein; MDA: Malondialdehyde; GSH: Reduced glutathione

\section{Acknowledgments}

The authors would like to thank Al-Aulaqi Specialized Medical Laboratory and Central Lab of Uni. of Sci. \& Tech. Hospital, Sana'a for their cooperation.

\section{Authors' contributions}

KMN conceptualized designed the study, acquired, analyzed, and interpreted the data, wrote the article, made critical revisions, and gave final approval of the version to be published. NSA performed, analyzed and interpreted the data, and drafted the article, made critical revisions. BYA designed the study, analyzed and interpreted the data, drafted the article, and made critical revisions. MRD edited the article, made critical revisions, and gave final approval of the version to be published.

\section{Funding}

This project has no funding.
Availability of data and materials

The datasets supporting the conclusions of this article are included within the article.

\section{Declarations}

Ethics approval and consent to participate

This study was carried out according to the criteria outlined in the "Guide for the Care and Use of Laboratory Animals" prepared by the National Academy of Sciences and published by the National Institute of Health. All protocols in this study were approved by the Committee of Experimental Animals Care and Use, Sana'a University (Mel/2014).

Consent for publication

Not applicable.

\section{Competing interests}

The authors declare that they have no competing interests.

\section{Author details}

'Department of Chemistry, Faculty of Science, Sana'a University, Sana'a, Yemen. ${ }^{2}$ Department of Chemical Ecology/Biological Chemistry, University of Konstanz, Universitätsstraße 10, 78464 Konstanz, Germany. ${ }^{3}$ Department of Biology, Faculty of Science, Sana'a University, Sana'a, Yemen. ${ }^{4}$ Department of Biochemistry, Mount Carmel College, Bengaluru, India.

Received: 19 September 2020 Accepted: 23 June 2021

Published online: 03 July 2021

\section{References}

1. Shishoo CJ, Shah SA, Rathod IS, Savale SS, Vora MJ. Impaired bioavailability of rifampicin in presence of isoniazid from fixed dose combination (FDC) formulation. Int J Pharm. 2001;228(1-2):53-67. https://doi.org/10.1016/S03785173(01)00831-6.

2. Tasduq SA, Peerzada K, Koul S, Bhat R, Johri RK. Biochemical manifestations of anti-tuberculosis drugs induced hepatotoxicity and the effect of silymarin. Hepatol Res. 2005;31(3):132-5. https://doi.org/10.1016/j.hepres.2 005.01.005.

3. Mahmoud AM, Ahmed OM, Galaly SR. Thymoquinone and curcumin attenuate gentamicininduced renal oxidative stress, inflammation and apoptosis in rats. EXCLI J. 2014;13:98-110. https://doi.org/10.17877/DE290R-4 51.

4. Georgieva NV, Gadjeva V, Tolekova A, Georgieva N, Gadjeva V. New isonicotinoylhydrazones with ssa protect against oxidative-hepatic injury of isoniazid. Trakia J Sci. 2004;2:37-43.

5. Tostmann A, Boeree MJ, Aarnoutse RE, Lange WCMD, Ven AJAMVD, Dekhuijzen R. Antituberculosis drug-induced hepatotoxicity: concise up-todate review. J Gastroenterol Hepatol. 2008;23(2):192-202. doi:https://doi.org/ 10.1111/j.1440-1746.2007.05207.x.

6. Guilford JM, Pezzuto JM. Natural products as inhibitors of carcinogenesis. Expert Opin Investig Drugs. 2008;17(9):1341-52. https://doi.org/10.1517/13 543784.17.9.1341.

7. Amin AR, Attur M, Abramson SB. Nitric oxide synthase and cyclooxygenases: distribution, regulation, and intervention in arthritis. Curr Opin Rheumatol. 1999;11(3):202-9. https://doi.org/10.1097/00002281-199905000-00009.

8. Billingham MEJ, Morley J, Hanson JM, Shipolini RA, Vernon CA. An antiinflammatory peptide from bee venom. Nature. 1973;245(5421):163-4. https://doi.org/10.1038/245163a0.

9. Kwon YB, Lee JD, Lee HJ, Han HJ, Mar WC, Kang SK, et al. Bee venom injection into an acupuncture point reduces arthritis associated edema and nociceptive responses. Pain. 2001;90(3):271-80. https://doi.org/10.1016/S03 04-3959(00)00412-7.

10. Son DJ, Lee JW, Lee YH, Song HS, Lee CK, Hong JT. Therapeutic application of anti-arthritis, pain-releasing, and anti-cancer effects of bee venom and its constituent compounds. Pharmacol Ther. 2007;115(2):246-70. https://doi. org/10.1016/j.pharmthera.2007.04.004.

11. Terwilliger TC, Eisenberg D. The structure of melittin. II. Interpretation of the structure. J Biol Chem. 1982;257(11):6016-22. https://doi.org/10.1016/S00219258(20)65098-0. 
12. Saini SS, Peterson JW, Chopra AK. Melittin binds to secretory phospholipase A2 and inhibits its enzymatic activity. Biochem Biophys Res Commun. 1997; 238(2):436-42. https://doi.org/10.1006/bbrc.1997.7295.

13. Park JH, Kim KH, Lee WR, Han SM, Park KK. Protective effect of melittin on inflammation and apoptosis in acute liver failure. Apoptosis. 2012;17(1):61-9. https://doi.org/10.1007/s10495-011-0659-0.

14. Nah S-S, Ha E, Lee H-J, Chung J-H. Inhibitory effects of melittin on the production of lipopolysaccharide-induced matrix metalloproteinase 3 in human osteoarthritic chondrocytes. Toxicon. 2007;49(6):881-5. https://doi. org/10.1016/j.toxicon.2006.12.007.

15. Stuhlmeier KM. Apis Mellifera venom and Melittin block neither NF-kB-p50 DNA interactions nor the activation of NF-kB, instead they activate the transcription of Proinflammatory genes and the release of reactive oxygen intermediates. J Immunol. 2007;179(1):655-64. https://doi.org/10.4049/ jimmunol.179.1.655.

16. Yun SW, Bae GS, Kim MS, Park KC, Koo BS, Kim BJ, et al. Melittin inhibits cerulein-induced acute pancreatitis via inhibition of the JNK pathway. Int Immunopharmacol. 2011;11(12):2062-72. https://doi.org/10.1016/j.intimp.2 011.08.020.

17. Lee $\mathrm{G}, \mathrm{Bae} \mathrm{H}$. Anti-inflammatory applications of melittin, a major component of bee venom: detailed mechanism of action and adverse effects. Molecules. 2016;21(5). https://doi.org/10.3390/molecules21050616.

18. National Research Council (US) Institute for Laboratory Animal Research. Guide for the Care and Use of Laboratory Animals. Washington (DC): National Academies Press (US); 1996. Available: http://www.ncbi.nlm.nih. gov/books/NBK232589/

19. Naji KM, Al-Shaibani ES, Alhadi FA, Al-Soudi SA, D'souza MR. Hepatoprotective and antioxidant effects of single clove garlic against CCl4induced hepatic damage in rabbits. BMC Complement Altern Med. 2017; 17(1):411. https://doi.org/10.1186/s12906-017-1916-8.

20. Shediwah FMH, Naji KM, Gumaih HS, Alhadi FA, Al-Hammami AL, D'Souza MR. Antioxidant and antihyperlipidemic activity of Costus speciosus against atherogenic diet-induced hyperlipidemia in rabbits. Journal of Integrative Medicine. 2019;17(3):181-91. https://doi.org/10.1016/j.joim.2019.02.002.

21. Ohkawa H, Ohishi N, Yagi K. Assay for lipid peroxides in animal tissues by thiobarbituric acid reaction. Anal Biochem. 1979;95(2):351-8. https://doi. org/10.1016/0003-2697(79)90738-3.

22. Moron MS, Depierre JW, Mannervik B. Levels of glutathione, glutathione reductase and glutathione S-transferase activities in rat lung and liver. Biochim Biophys Acta Gen Subj. 1979;582(1):67-78. https://doi.org/10.1016/ 0304-4165(79)90289-7.

23. Lowry OH, Randall RJ. Protein measurement by the Folin reagent. J Biol Chem. 1951;193(3):265-75. https://doi.org/10.1016/0304-3894(92)87011-4

24. Osei-Bimpong A, MCLEAN R, Bhonda E, Lewis SM. The use of the white cell count and haemoglobin in combination as an effective screen to predict the normality of the full blood count. Int J Lab Hematol. 2012;34(1):91-7. doi:https://doi.org/10.1111/j.1751-553X.2011.01365.X.

25. Humason $\mathrm{GL}$, others. Animal tissue techniques. Animal tissue techniques. 1962. Available: http://www.cabdirect.org/abstracts/19622204447.html

26. Gibson-Corley KN, Olivier AK, Meyerholz DK. Principles for valid histopathologic scoring in research. Vet Pathol. 2013;50(6):1007-15. https:// doi.org/10.1177/0300985813485099.

27. Kulathuran Pillai K, Chidambaranathan N, Mohamed Halith M, Jayaprakash S, Narayanan N. Hepatoprotective activity of Cnidoscolus chayamansa against rifampicin and isoniazide induced toxicity in wistar rats. Res J Pharm, Biol Chem Sci. 2012;3:577-85.

28. Nalpas B, Vassault A, Charpin S, Lacour B, Berthelot P. Serum mitochondrial aspartate aminotransferase as a marker of chronic alcoholism: diagnostic value and interpretation in a liver unit. Hepatology. 1986;6(4):608-14. https://doi.org/10.1002/hep.1840060410.

29. Thapa BR, Walia A. Liver function tests and their interpretation. Indian J Pediatr. 2007;74(7):663-71. https://doi.org/10.1007/s12098-007-0118-7.

30. Kaplan MM. Serum alkaline phosphatase-another piece is added to the puzzle. Hepatology. 1986;6(3):526-8. https://doi.org/10.1002/hep.1840060334.

31. Ramaiah SK. A toxicologist guide to the diagnostic interpretation of hepatic biochemical parameters. Food Chem Toxicol. 2007;45(9):1551-7. https://doi. org/10.1016/j.fct.2007.06.007.

32. Kim KH, Sung HJ, Lee WR, An HJ, Kim JY, Pak SC, et al. Effects of melittin treatment in cholangitis and biliary fibrosis in a model of xenobioticinduced cholestasis in mice. Toxins. 2015;7(9):3372-87. https://doi.org/10.33 90/toxins7093372.
33. Wang X, Zhai W. Cellular and biochemical effects in the bronchoalveolar lavage fluid of the rats exposed to fenvalerate. Chin J Pharmacol Toxicol. 1988;4:6.

34. Lee WR, Park JH, Kim KH, Park YY, Han SM, Kyu Park K. Protective effects of melittin on transforming growth factor- $\beta 1$ injury to hepatocytes via antiapoptotic mechanism. Toxicol Appl Pharmacol. 2011;256:209-15. https://doi. org/10.1016/j.taap.2011.08.012.

35. Goh Z-H, Tee JK, Ho HK. An evaluation of the in vitro roles and mechanisms of Silibinin in reducing pyrazinamide- and isoniazid-induced hepatocellular damage. Int J Mol Sci. 2020;21(10):3714. https://doi.org/10.3390/ijms21103 714.

36. Attri S, Rana SV, Vaiphei K, Sodhi CP, Katyal R, Goel RC, et al. Isoniazid - and rifampicin-induced oxidative hepatic injury - protection by $\mathrm{N}$ acetylcysteine. Hum Exper Toxicol. 2000;19(9):517-22. https://doi.org/10.11 91/096032700674230830.

37. Naik SR. Antioxidants and their role in biological functions: An overview. Indian Drugs. 2003:40:501-16.

38. Sodhi CP, Rana SV, Mehta SK, Vaiphei K, Attari S, Mehta S. Study of oxidative-stress in isoniazid-rifampicin induced hepatic injury in young rats. Drug Chem Toxicol. 1997;20(3):255-69. https://doi.org/10.3109/0148054 9709003881.

39. Hassan RHS. Possible Protective Role of Gene Expression of Certain Enzymes in Experimentally Induced Fulminant Hepatic Failure in Rats.Cairo University; 2015. http://www.erepository.cu.edu.eg/index.php/cutheses/article/view/4 766. Accessed 14 Mar 2020.

40. Rieder $\mathrm{H}$. Interventions for tuberculosis control and elimination. Paris: International Union Against Tuberculosis and Lung Disease; 2002.

41. Sei WL, Young AK, Young SY, Um SW, Sang ML, Yoo CG, et al. The prevalence and evolution of anemia associated with tuberculosis. J Korean Med Sci. 2006;21(6):1028-32. https://doi.org/10.3346/jkms.2006.21.6.1028.

42. Lewis CR, Manoharan A. Pure red cell hypoplasia secondary to isoniazid. Postgrad Med J. 1987;63(738):309-10. https://doi.org/10.1136/pgmj.63.738.3 09.

43. Yunis AA, Arimura GK, Lutcher CL, Blasquez J, Halloran M. Biochemical lesion in Dilantin-induced erythroid aplasia. Blood. 1967;30(5):587-600. https://doi. org/10.1182/blood.V30.5.587.587.

44. Goldman AL, Braman SS. Isoniazid: a review with emphasis on adverse effects. Chest. 1972;62(1):71-7. https://doi.org/10.1378/chest.62.1.71.

45. Arundhathi S, Kumar AA, Kumar YRK and BA. Haematological and Histopathological Alterations Due to Combined Toxicity of Isoniazid and Rifampicin; Amelioration with Withania Somnifera and Vitamin-E in Wistar Rats, vol. 6; 2015. p. 222-9. Available: https://ijpbs.net/details.php?article= 4523

46. Neuwirt J, Poňka P, Neuwirt J, Poňka P. Regulation of Haemoglobin synthesis. Regulation of Haemoglobin Synthesis. 1977:135-48. https://doi. org/10.1007/978-94-010-1090-0_5.

47. Ross JD, Horne NW. Drugs used in chemotherapy. 1st Indian ed. Modern drug treatment in tuberculosis. 1st Indian ed. New Delhi: Oxford University Press; 1992. p. 1-17. Available: https://www.cabdirect.org/cabdirect/abstra ct/19842009737

48. Orazi A. Histopathology in the diagnosis and classification of acute myeloid leukemia, myelodysplastic syndromes, and myelodysplastic/ myeloproliferative diseases. PAT. 2007;74(2):97-114. https://doi.org/10.1159/ 000101709.

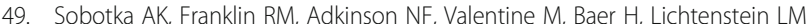
Allergy to insect stings: II. Phospholipase a: the major allergen in honeybee venom. J Allergy Clin Immunol. 1976;57(1):29-40. https://doi.org/10.1016/ 0091-6749(76)90076-2.

50. Abdelrahman EG, Gasim GI, Musa IR, Elbashir LM, Adam I. Red blood cell distribution width and iron deficiency anemia among pregnant Sudanese women. Diagn Pathol. 2012;7(1):168. https://doi.org/10.1186/1746-1596-7-168.

51. Abdelhalim MAK, Jarrar BM. Gold nanoparticles induced cloudy swelling to hydropic degeneration, cytoplasmic hyaline vacuolation, polymorphism, binucleation, karyopyknosis, karyolysis, karyorrhexis and necrosis in the liver. Lipids Health Dis. 2011;10(1):166. https://doi.org/10.1186/1476-511X-10-166.

52. Lee YA, Wallace MC, Friedman SL. Pathobiology of liver fibrosis: a translational success story. Gut. 2015;64(5):830-41. https://doi.org/10.1136/ gutjnl-2014-306842.

53. Pinzani M, Macias-Barragan J. Update on the pathophysiology of liver fibrosis. Expert Rev Gastroenterol Hepatol. 2010;4(4):459-72. https://doi.org/1 0.1586/egh.10.47. 
54. Park JH, Kum YS, Lee TI, Kim SJ, Lee WR, Kim Bl, et al. Melittin attenuates liver injury in thioacetamide-treated mice through modulating inflammation and fibrogenesis. Exp Biol Med. 2011;236(11):1306-13. https://doi.org/10.12 58/ebm.2011.011127.

55. Park JH, Lee WR, Kim HS, Han SM, Chang YC, Park KK. Protective effects of melittin on tumor necrosis factor-a induced hepatic damage through suppression of apoptotic pathway and nuclear factor-kappa B activation. Exp Biol Med. 2014;239(12):1705-14. https://doi.org/10.1177/1535370214533 880.

56. Morales $\mathrm{P}$, Kin J-Y, Leem J, Hong H-L. Melittin ameliorates endotoxininduced acute kidney injury by inhibiting inflammation, oxidative stress, and cell death in mice. Oxidative Med Cell Longev. 2021;2021(special issue):1-14. https://doi.org/10.1155/2021/8843051.

57. Kia A, McAvoy K, Krishnamurthy K, Trotti D, Pasinelli P. Astrocytes expressing ALS-linked mutant FUS induce motor neuron death through release of tumor necrosis factor-alpha. Glia. 2018;66(5):1016-33. https://doi.org/10.1 002/glia.232988.

58. Moon DO, Park S-Y, Lee K-J, Heo MS, Kim K-C, Kim M-O, et al. Bee venom and melittin reduce proinflammatory mediators in lipopolysaccharidestimulated BV2 microglia. Int Immunopharmacol. 2007;7(8):1092-101. https://doi.org/10.1016/j.intimp.2007.04.005.

\section{Publisher's Note}

Springer Nature remains neutral with regard to jurisdictional claims in published maps and institutional affiliations.

Ready to submit your research? Choose BMC and benefit from:

- fast, convenient online submission

- thorough peer review by experienced researchers in your field

- rapid publication on acceptance

- support for research data, including large and complex data types

- gold Open Access which fosters wider collaboration and increased citations

- maximum visibility for your research: over $100 \mathrm{M}$ website views per year

At BMC, research is always in progress.

Learn more biomedcentral.com/submissions 